\title{
PRÓlOGO: UNA TAREA FASCINANTE
}

\author{
Antonio NARBONA \\ Universidad de Sevilla
}

Me piden las editoras unas palabras que sirvan de antesala a la presentación de este volumen, que, obviamente, a ellas corresponde hacer. Nada de lo que pueda decir es nuevo. Pero aquí van, sin orden ni concierto, unas observaciones que se han ido instalando en mi mente tras impartir durante algunos cursos académicos en la Universidad Hispalense un Seminario con idéntico título: Oralidad en la escritura.

Solía decir W. Oesterreicher, a quien -junto con P. Koch- debemos el más claro e iluminador planteamiento de las recíprocas relaciones entre oralidad y escritura (o, como él prefería, escrituralidad), que la búsqueda de huellas y vestigios de la primera en la segunda constituía la tarea más fascinante para un lingüista o historiador de la lengua. En más de una ocasión le dije que estaba en lo cierto, pero que tenía tanto de problemática como de apasionante. Incluso llegué a sugerirle que se podía tomar prestado el final del título utilizado por Dámaso Alonso a propósito de las dificultades de interpretación de un texto literario medieval: «La bella de Juan Ruiz, toda problema».

No puede decirse que la llamada de atención del llorado filólogo alemán haya pasado inadvertida. En los últimos años, apenas se encontrará estudio lingüístico que no trate, con mayor o menor detenimiento, de tal interrelación, únicamente posible, claro es, si de lo oral y lo escrito se tiene una concepción no estricta ni principalmente medial, y no dicotómica, sino gradual y pluriparamétrica. Trabajos de Silvia Iglesias, como «La evolución histórica de pues como marcador discursivo hasta el siglo XV» $\mathrm{y}$ «Oralidad y escritura en la Edad Media: observaciones sobre la historia de $c a$ y que», ambos publicados el año 2000, o la Tesis Doctoral de Araceli López Serena (2004), convertida en libro tres años después (Oralidad y escrituralidad en la recreación literaria del español coloquial), pueden servir de ejemplos modélicos de la respuesta dada para el español. No podía estar en mejores manos la preparación de este monográfico de Oralia.

Conviene recordar que no se trata de una labor novedosa. Al contrario, nunca ha dejado de preocupar averiguar lo que se pueda de cómo se ha- 
blaba en el pasado. Hasta hace muy poco tiempo, las fuentes escritas eran las únicas utilizables. Y cuando ha dejado de ser cierto eso de que VERBA VOLANT, casi nadie ha prescindido de los textos a la hora de aducir datos que prueben la validez de una explicación o el carácter plausible de una hipótesis sobre lo oral. Es más, tal vía indirecta de acceso se ha revelado, para algunos propósitos, más rentable que el recurso exclusivo a actuaciones conversacionales reales, que, por lo demás, casi siempre se considera necesario transcribir para su observación y análisis. Incluso disponiendo de tradiciones discursivas idóneas, no es fácil atinar en la interpretación de los fenómenos orales, entre otras razones porque al lingüista le cuesta liberarse de la deformación jerárquica que ha mediatizado su quehacer, lo que le impide proyectar el principio de la relatividad de la variación, es decir, abandonar la inclinación a contemplar las modalidades de uso desde la óptica impuesta por la fijada como eje de referencia.

De todos modos, la cuestión de los datos ha dejado (o está dejando) de ser el único y principal obstáculo. Y tampoco creo que, ante la comprobación de que no son adecuadas muchas de las unidades que han venido sirviendo hasta ahora, la necesidad de otras específicas deba frenar la investigación. De hecho, la atención creciente a ciertas macrocategorías pragmáticas, como la atenuación o la intensificación, o a los denominados marcadores del discurso (que ha generado una bibliografía literalmente inabarcable), refleja el convencimiento de que es la peculiar técnica constructiva puesta en funcionamiento en las actuaciones propias de la zona de la inmediatez o proximidad comunicativa lo que debe situarse en primer plano de la investigación. Pero es mucho lo que falta por saber de la sintaxis discursiva, en parte, porque el rastreo de los esquemas constructivos va a estar siempre condicionado por la imposibilidad de trazar líneas separadoras en el continuum gradual de las variedades, orales y escritas, y en parte, por la necesidad de incorporar factores contextuales relevantes, empezando por los prosódicos, a los que -en solidaridad con los patrones sintácticos- se encomienda el sentido transmitido. Me temo que van a tardar en llegar las respuestas satisfactorias a las preguntas cruciales que el investigador de lo oral en lo escrito debe hacerse desde el inicio mismo. ¿En qué medida es posible el trasvase de lo primero a lo segundo? Si parece claro que no cabe el calco, pues nadie puede escribir como habla ¿qué puede ser imitado (mímesis de lo oral, escritura del habla) y qué no, o difícilmente, y por qué? ¿Por y para qué se toma una decisión que va a obligar al receptor a mutarse en oyente interpuesto de intervenciones en mayor o menor grado orales pero que han sido puestas por escrito? El éxito del experimento, pues de eso se trata (en ocasiones, «de alto riesgo»), no depende únicamente de que el escritor acierte en la captación de lo oral, sino de la competencia de los lectores para actualizar, recuperar y reponer, lo mucho que ningún código gráfico 
puede reflejar. No extraña que tal operación se haya conseguido en época reciente, y por los muy pocos autores que han ensayado -con desigual fortuna- la conversión del lenguaje coloquial en literario o por aquellos (más numerosos) que salpican sus colaboraciones periodísticas -también con diferente acierto- de pinceladas coloquiales. No hace falta decir que los fines perseguidos por unos y otros no coinciden.

Trabajo no falta. Estoy seguro de que las colaboraciones aquí recogidas van a ir rellenando algunos de los huecos a que aluden las interrogantes abiertas. Paso a paso se va avanzando. 